\section{Multidisciplinary \\ SCIENTIFIC JOURNAL OF \\ MARITIME RESEARCH}

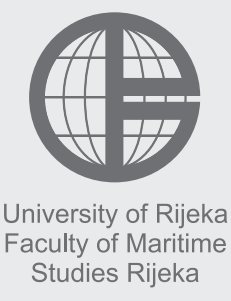

Multidisciplinarni

znanstveni časopis

POMORSTVO

\title{
Analysis of the multiplicative effects of the Port of Rijeka
}

\author{
Ana Perić Hadžić, Luka Župarić, Sara Đeverlija \\ University of Rijeka, Faculty of Maritime Studies, Studentska 2, 51000 Rijeka, Croatia, e-mail: ana@pfri.hr
}

\section{ABSTRACT}

The Port of Rijeka is an important transport hub of international importance for the Republic of Croatia. With its geostrategic predispositions and increasingly strong appearance in transport sector, the Rijeka gateway is gaining more and more significance. As a key hub between the maritime and inland traffic systems, the Port of Rijeka encompasses a whole range of active and passive participants in process of creating port services. Positive economic effects of the port's traffic on its regional area are manifested through multiplicative effects arising from participation in port services. By calculating different multiplicative effects, it is possible to get a better insight into commercial-economic interconnection of port services providers within the Rijeka port system. This paper confirms that the revenues generated by the traffic of cargo and passengers achieve 3 to 10 times greater effect on the overall market, and directly or indirectly influence at least $0.15 \%$ to at most $1.55 \%$ of the national GDP.

\section{ARTICLE INFO}

Review article

Received 15 November 2016

Accepted 5 December 2016

\section{Key words:}

Port of Rijeka

Rijeka traffic route

Traffic analysis

Multiplicative effects

\section{Introduction}

An international public port represents a traffic, commercial, industrial and goods-distribution hub which, according to the nature of its geostrategic and geo-traffic position, technologically and organizationally integrates maritime and inland traffic into a unique transport system. Considering that goods are common subject of activities of all the participants in the transport and economic system, all participants' functions in cargo traffic are determined by the demands of those goods, i.e. of the buyer or user of transport services. In such circumstances the port cannot be seen as a closed operative transport economic system, but solely as an integrating factor which, by its interactive operations, ensures a dynamic function and development of subordinate and supraordinate systems [1,87].

Therefore, the port's main activity is handling of cargo, which is reflected in the port enabling easier, safer and faster transport of goods and passengers between maritime and inland transport providers. To perform this activity, the port must satisfy certain requirements, such as adequate shipment capacity with regards to the port infrastructure, port superstructure and equipment i.e. mecha- nisation. In doing so, the port must have a good mainland connection with the hinterland, as well as good maritime connections. The port will achieve total affirmation and optimal operation of its traffic functions only if its capacity, the transport capacity of mainland infrastructure and the port's facade are coordinated and synchronised. If either one of those elements is not optimally dimensioned, it will create a bottleneck in flow of traffic and limit the traffic possibilities of others $[2,81]$.

\section{Port of Rijeka - an international generator of economic development}

Today the Port of Rijeka is an important hub in the maritime traffic of central and east European countries. It is an integral part of the North Adriatic port system and it significantly contributes to the development of the Croatian economy. With the Republic of Croatia joining the European Union, the market position of the Port of Rijeka and Rijeka Gateway was put on a par with other competitive ports and gateways. Apart from that, the changes happening on a global level indicate an increasing reaffir- 
mation of the Mediterranean and the Adriatic in terms of maritime traffic, which for the Port of Rijeka means additional strengthening of its market position, especially regarding maritime trade between Europe and the Far East. The Port of Rijeka, like any other port, functions within a larger transport system. From the traffic point of view, the Port of Rijeka functions as an element within the Rijeka gateway system.

Key sides in the system of traffic infrastructure relevant to the transport of cargo and port activities are ports and relevant railway and road operators. The specific position of the Port of Rijeka is characterised by an absence of quality flat areas by the shore, which makes the development of port activities difficult and expensive. Besides the depth of the sea, it would be of utmost importance to base the gateway, in its development as a whole, on modern transport technologies and the most up-to-date technological solutions in planning the development of Rijeka and its wider surrounding area regarding traffic and traffic terminals, for the transport of passengers and especially for the transport of cargo. Delays in the construction of the Rijeka bypass, construction of the motorway between Zagreb and Rijeka, and reconstruction of the Rijeka railway junction have led to stagnation in the development of the traffic system of the Republic of Croatia, but also to stagnation in the development in the city of Rijeka, its port included. Considerably weaker railway and road connections to the Port of Rijeka, as well as insufficient poor-quality facilities on the mainland obstruct the development of the port. The system of the Port of Rijeka is also inappropriate connected with road and railway connections. Those connections are realised through the very city centre, which creates unfavourable relations between the City and the Port of Rijeka. This problem can be solved with a gradual development of the City and the Port of Rijeka as a whole, with functional integrations of developmental components of the port, terminals and city centre [3].

In accordance with the Maritime Domain and Seaport Act, the Port of Rijeka is classified as a port of international economic importance for the Republic of Croatia, and as such it generates numerous positive effects for the national economy [4]. This is confirmed by many concessionaires of the Port of Rijeka Authority who perform various port and transport activities in the port area. Croatia's accession to the EU opened many possibilities in the port area, such as the elimination of the customs zone, better circulation of goods between Croatia and other EU countries, direct domestic and foreign investments, and most of all, connecting the European and Asian markets. In order for the Port of Rijeka to restore its former position on world market it is necessary to integrate all factors that have an influence and that benefit from port operations.

The Port of Rijeka Authority, together with their biggest concessionaire Port of Rijeka d.d., are facing a new challenge of realising strategic projects important for the city of Rijeka and fir the Republic of Croatia. Those are projects such as Gateway and Waterfront, extension of the warehouse-production zone Škrljevo, which is connected to national strategic projects such as the "Lowland Railway Rijeka-Zagreb", traffic-logistics centre "Miklavije" and extension of industrial zone Kukuljanovo [1].

The port of Rijeka is a multi-purpose port which is manipulated with almost all types of cargo. The main infrastructure and superstructure capacities consist of General Cargo Terminal, Grain Terminal, Liquid Cargo Terminal, Container Terminal Brajdica, Dry Bulk Cargo Terminal, Bakar Goranin Ro-Ro Terminal, Škrljevo Terminal, Raša Bršica Terminal, Passenger Port Terminal.

Annual capacities per terminals and types of cargo [5]:

- Rijeka (general): 2 mil. t;

- Rijeka (timber): 0.5 mil. t;

- Rijeka (frozen): 0.1 mil. t;

- Silos (crops): 1 mil. t;

- Bakar (bulk): 4 mil. t;

- Bršica (cattle, timber, general, bulk): 0.6 mil. t;

- Omišalj (liquid): 24 mil. t;

- AGCT (containers): 0.6 mil. TEU-a

Port of Rijeka d.d. is a joint-stock company which on the basis of concession agreements performs port and many other economic activities in the Port of Rijeka area. Port of Rijeka d.d. is the largest concessionaire for transhipment of dry cargo in the Port of Rijeka area, and a market-oriented company which on the basis of an agreement on primary concession performs the main port operation services. Port of Rijeka d.d. is the holder of primary concession between 2012 and 2042 [6]. Port of Rijeka d.d. is still mostly state-owned ( $83 \%$ ), while the other shareholders have individual shares of less than $2 \%$. It is constituted as a company whose main activity is performance of port operations: loading, unloading, transhipment, warehousing, transport of general cargo, timber, grain cargo, liquid and bulk cargo, cattle, bananas, citrus and other fruits, wheat, soy and other crops; docking and undocking ships on the Port of Rijeka as well as other economic activities such as servicing port mechanization, maintenance of substructure and superstructure, cargo anchorage, covering and insuring cargo and transport vehicles, using the substructure, superstructure and maritime objects [6]. In cooperation with other concessionaires and participants, it performs the transhipment of goods, warehousing, servicing of port mechanization, maintenance and usage of substructure and superstructure, cargo anchorage, covering and insuring of cargo, quality and quantity control etc. on eight specialized terminals [7].

\section{Analysis of the Port of Rijeka traffic}

The total traffic of all dry cargo in the Port of Rijeka (Port of Rijeka d.d. and Adriatic Gate Container Terminal) in 2014 was 4.14 mil tons. This is an increase of $15 \%$ compared to the previous year when 3,602,220 tons of cargo were transported. In 2014 Port of Rijeka d.d. had traffic of $2,773,000$ tons of dry cargo, which represents an increase of $17 \%$ compared to 2013 . 


\subsection{Cargo traffic}

In regards to the structure of cargo, the largest growth was recorded in the traffic of bulk cargo which increased by $70 \%$, and the traffic of timber which grew by $24 \%$. In this group of cargo, the biggest increase was recorded in the shipment of coal and iron ore on the Terminal for bulk cargo in Bakar, where 1.08 mil tons of iron ore, coal and cement were shipped. The high growth is a result of a new deal made in 2014 with an Austrian partner who had considerable cargo in the Port of Rijeka before the war, but was gone for years after that [8].

In 2014 Port of Rijeka d.d. achieved an operative traffic of 791,908 tons of general cargo, which is a decrease of $29 \%$ compared to 2013 . Black metallurgy semi-products participate with $48 \%$ in the traffic of general cargo; shipped quantities of these products have fallen, which is a reflection of the condition of the overseas market of technical interventions in ironworks [8]. These are followed by bulk cargo for which the Terminal Silos in Rijeka basin and Terminal Bakar in Bakar basin are specialised. Container traffic is connected to loading/unloading and lodging of containers and is tightly related to the traffic of AGCT Container Terminal on Brajdica, as well as the future Container Terminal of similar capacity on Zagreb pier, which the Port of Rijeka Authority has yet to build and concession. The following graph shows the financial analysis of the Port of Rijeka d.d.'s total cargo per main groups of cargo in the period between 2012 and 2014.

The dominance of general cargo in the financial structure of revenue per groups of cargo for the period 20122014 is clearly visible from the graph. Approximately $63 \%$ of revenue in 2014 came from general cargo while the financial realisation coming from bulk cargo represents about $32 \%$ of the total revenue. The remaining $5 \%$ refer to container traffic [8]. It should be emphasised that the revenue of Adriatic Gate d.d. and Container Terminal Brajdica is not included in the revenue from container traffic.

\subsection{Passenger traffic}

Even though according to Jadrolinija d.d. more than 2 mil passengers were transported in 2014 in Rijeka waters, only 150,000 passengers refer to the Port of Rijeka. Additional ten thousand passengers came from cruise ships and other tourist sources. It is to be mentioned that shore line Rijeka-Split-Dubrovnik was cancelled in 2015, which will have an effect on the future indicators of passenger traffic.

Table 1 The structure of cargo for year 2013 and 2014

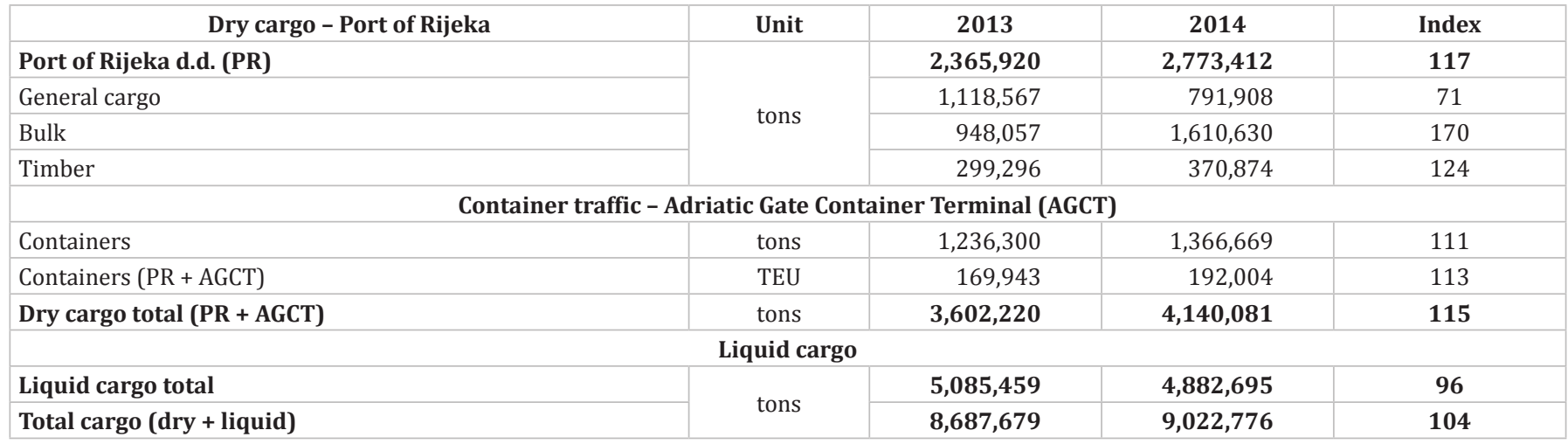

Source: Made by the author according to data of the Port of Rijeka Authority from http://www.portauthority.hr (15.03.2016)

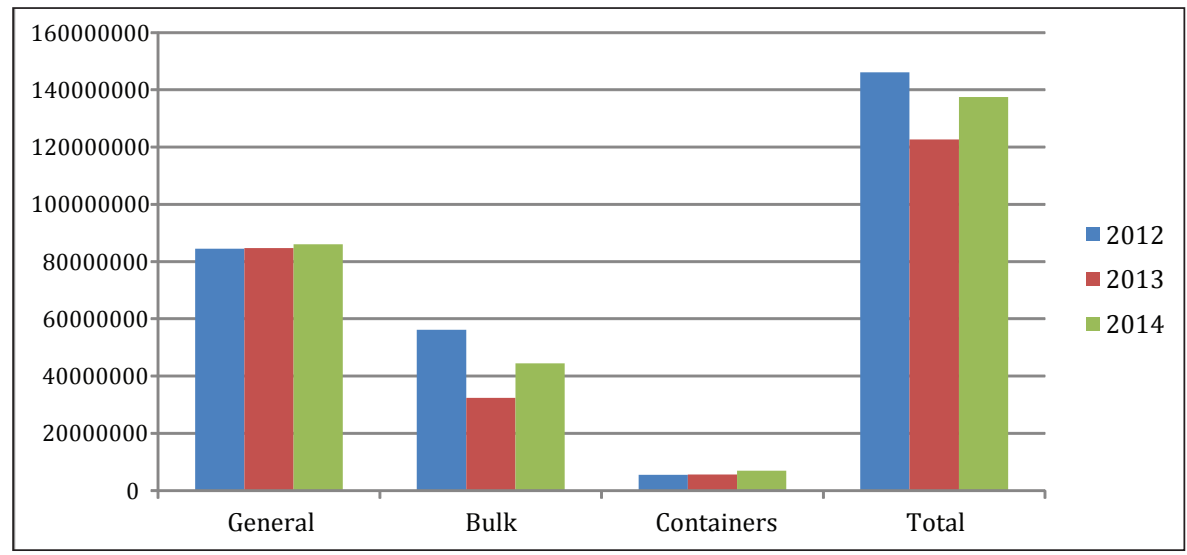

Figure 1 Financial realisation of Port of Rijeka d.d. per groups of traffic between 2012 and 2014 
Table 2 The structure of passenger traffic in 2013 and 2014

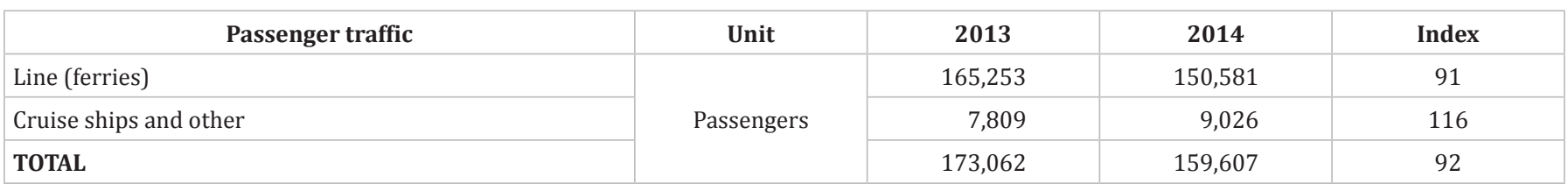

Source: Made by the author according to data of the Port of Rijeka Authority from http://www.portauthority.hr (02.02.2016)

Under the consideration that every line passenger paid a ticket at the average price of $50 \mathrm{kn}$, it is possible to get the amount of $7.5 \mathrm{mil} \mathrm{kn}$ of proceeds from passenger tickets. Even though that amount was surely exceeded, proceeds from vehicles will not be included in further figures, due to the cancellation of ro-ro passenger part of the service.

\section{Multiplicative factors and effects of the traffic in the Port of Rijeka}

In an economic context, the port functions as a multiplicative financial factor for all participants of business processes, direct or indirect, but also for the whole area of port activities. Multimodality of the traffic in seaports implies the crossing of many traffic sectors, involving a wide spectrum of participants, from those directly involved, such as transport, (un)loading and warehousing service providers, to those indirectly involved, such as administration bodies, supply and hospitality services, whose business depends on the existence of traffic between directly involved participants.

\subsection{Methods and approach to the analysis of traffic multiplicative effects}

A traffic multiplicative effect is the overall quantity of achieved revenue of all participants in the traffic. Participants can be direct or indirect, active or passive, and, depending on applied criteria, a wide spectrum of physical and legal entities can be considered a participant in traffic. Revenues of all participants coming directly from the traffic, but also after the realisation of cargo and passenger traffic, are considered traffic multiplicative effect revenues. This paper will include only direct traffic effects and participants, because an all-encompassing survey of all exact primary and secondary effects would require a multiannual research and participation of a large number of staff and participants. For that reason, the authors try to establish the real minimal direct multiplicative consequences which are realised in cargo and passenger traffic in the port. Only certain direct revenue achieved by the participants in linear traffic, without additional manipulations, storage charges, warehousing charges, fines, inspections etc. will be taken into consideration in the calculations. In principle, the authors will try to calculate the certain effect of the port traffic on the revenue achieved in its surroundings. Cargo traffic is considered the source of primary revenue, while a provider of port services is considered a primary participant. In the calculations, secondary direct participants in cargo traffic are direct revenues of other participants in the flow of traffic through the port transport system on an annual level, according to the data from 2014. It is possible to establish how many units of revenue are achieved by the whole surroundings due to a primary participant achieving revenue from the traffic of cargo and passengers.

Primary direct participants in the Port of Rijeka are individual providers of port services i.e. main concessionaires Port of Rijeka d.d. and Adriatic Gate d.d. (AGCT). In the calculations, direct but secondary participants in the traffic are the Port of Rijeka Authority (port fees), Plovput d.d. (light dues and maintenance of maritime routes), as well as mainland transport providers such as HŽ Cargo d.o.o. (for bulk and general cargo), Janaf d.d. (for liquid cargo), AGCT d.o.o. (for container cargo), and Jadrolinija d.d. and Krilo d.o.o. for passenger transport. Official tariffs and data from official websites and reports of Port of Rijeka d.d., AGCT, Plovput d.o.o., Port of Rijeka Authority, HŽ Cargo d.d., Janaf d.d., Jadrolinija d.d. and Krilo d.o.o are taken into consideration.

The category of other participants was added to the calculation; this category includes at least one more direct participant (agencies, sales, warehouse, additional fees, piloting, towage etc.) which wasn't taken into consideration alongside previously listed participants due to a lack of publicly available data. It was approximated that at least one additional activity or at least one additional participant which has a multiplicative effect on the surroundings was surely achieved for every twentieth ton or TEU or passenger. In the calculations this was justified as $5 \%$ of direct revenues achieved up to that point. With the calculations it is possible to calculate the multiplicative factors (i.e. relation between the overall revenue and revenue of primary participants) arising from the traffic of certain cargo or passenger categories.

$$
M=\frac{\text { traffic multiplicative effects revenue }}{\text { primary participants revenue }}
$$

\subsection{Total multiplicative effects of the traffic in the Port of Rijeka}

If the overall multiplicative effects are viewed, the successful conduction of traffic in the multimodal port system generates three times greater multiplicative effect on the wider area (Table 3 ). 
Table 3 Revenues and multiplicated revenues per types of traffic in 2014

\begin{tabular}{|c|c|c|c|c|}
\hline & Tons & Revenue (kn) & Multiplicative factor & Multiplicated revenue (kn) \\
\hline General cargo & $1,162,782$ & $86,045,868$ & 2.6 & $224,039,022$ \\
\hline Bulk cargo & $1,610,630$ & $44,437,282$ & 5.09 & $226,057,558$ \\
\hline Liquid cargo & $4,882,695$ & $237,201,323$ & 1.23 & $292,321,579$ \\
\hline \multicolumn{5}{|c|}{ TEU } \\
\hline Container traffic & 192,004 & $132,234,065$ & 6.54 & $864,272,799$ \\
\hline \multicolumn{5}{|c|}{ Passengers } \\
\hline Passengers traffic (line) & 150,581 & $7,529,050$ & 1.33 & $10,013,576$ \\
\hline \multirow[t]{2}{*}{ Passenger traffic (cruise ships) } & 9,026 & 224,033 & 5.97 & $1,338,549$ \\
\hline & TOTAL & $507,671,621$ & 3.19 & $1,618,043,083$ \\
\hline
\end{tabular}

Source: Made by the authors

Regarding the table 3, it is evident that in 2014 the Port of Rijeka achieved at least $507.6 \mathrm{mil} \mathrm{kn}$ of revenues and in doing so produced the overall multiplicated revenue of at least 1,618.0mil kn ( $\left.\mathrm{M}_{\text {PortRijeka }}=3.19\right)$, alongside other participants. The categories of traffic which achieved the highest multiplicative factors are container traffic $\left(M_{\text {cont }}=6.54\right)$, cruise ship traffic $\left(M_{c s}=5.97\right)$ and bulk cargo traffic $\left(\mathrm{M}_{\text {bulk }}=5.09\right)$. It is not redundant to once again mention that all calculations are approximate and done with the lowest possible values, and that the revenue of shipping companies is not included.

\subsubsection{Theoretical multiplicative effects of the Port of Rijeka capacities}

Calculated results and pertaining multiplicative effects comprise the cargo transported in the Port of Rijeka in 2014. However, with such cargo volume most capacities did not even nearly achieve their maximal or optimal annual results. The utilization of $60-70 \%$ of dynamic capacities on an annual level is considered optimal utilization of capacities. The following table (Table 4) shows the theoretical effects achievable at a maximal utilization of annual capacities of individual terminals with calculated minimal revenue per ton/TEU/passenger.

The effects shown in the previous table refer to utilization of all capacities of $100 \%$, which in practice isn't real, not is it organizationally or operatively feasible. Therefore, in the following calculations the authors took into consideration the optimal utilization levels of all individual annual capacities per terminals i.e. $70 \%$ of their capacity. In accordance with that, Table 5 shows the maximal achievable revenue and optimal achievable revenue (at the level of $70 \%$ of the annual port capacity result), as well as the multiplicative effects achievable in cases of maximal and optimal utilization of capacities.

It is visible from the table that, at optimal utilization of the Port of Rijeka existing capacities, the best results would be achieved by container, liquid and bulk cargo categories. It is possible to conclude that in case of an optimal

Table 4 Revenues at maximal annual capacities

\begin{tabular}{|l|c|c|c|}
\hline & Tons & $\begin{array}{c}\text { Lowest revenue } \\
\text { (kn/t) }\end{array}$ & $\begin{array}{c}\text { Maximal achievable } \\
\text { revenue (kn) }\end{array}$ \\
\hline Terminal for general cargo & $2,000,000$ & 74.0 & $148,000,000$ \\
\hline Terminal for bulk cargo & $4,000,000$ & 27.6 & $110,400,000$ \\
\hline Terminal for crops & $1,000,000$ & 27.6 & $27,600,000$ \\
\hline Terminal for liquid cargo & $24,000,000$ & 24.3 & $382,960,000$ \\
\hline Terminal for timber & 500,000 & 74.0 & $37,000,000$ \\
\hline & TEU & $\begin{array}{c}\text { Lowest revenue } \\
\text { (kn/TEU) }\end{array}$ & $413,220,000$ \\
\hline Container Terminal Brajdica & 600,000 & 688.7 & $\begin{array}{c}\text { Lowest revenue } \\
\text { (kn/passenger) }\end{array}$ \\
\hline & Passengers & 50 & $10,000,000$ \\
\hline Passenger (line) & 200,000 & 20,000 & 490,200 \\
\hline Passenger (cruise ships and other)* & & \\
\hline
\end{tabular}

Source: Made by the authors

* Revenues per passenger increased by minimal fees payable by cruise ships are included in the calculation of maximal achievable revenue in the category of passenger traffic (cruise ships and other). In this case the projections of maximal revenues included 15 (that many arrivals are expected in 2015 ) individual fees per vessel in the amount of $300 €$. 
Table 5 Maximal and optimal theoretical revenue and maximal and optimal multiplicative effects (in kn)

\begin{tabular}{|c|c|c|c|c|c|}
\hline & $\begin{array}{l}\text { Max achievable } \\
\text { revenue }\end{array}$ & $\begin{array}{l}\text { Revenue - opt. } \\
\text { result (70 \%) }\end{array}$ & $\begin{array}{l}\text { Mult. } \\
\text { factor }\end{array}$ & $\begin{array}{l}\text { Max mult. } \\
\text { effect }\end{array}$ & $\begin{array}{l}\text { Multiplicative } \\
\text { effect (70\%) }\end{array}$ \\
\hline Terminal for general cargo & $148,000,000$ & $103,600,000$ & 2.6 & $384,800,000$ & $269,360,000$ \\
\hline Terminal for bulk cargo & $110,400,000$ & $77,280,000$ & 5.09 & $561,936,000$ & $393,355,200$ \\
\hline Terminal for crops & $27,600,000$ & $19,320,000$ & 5.09 & $140,484,000$ & $98,338,800$ \\
\hline Terminal for liquid cargo & $582,960,000$ & $408,072,000$ & 1.23 & $717,040,800$ & $501,928,560$ \\
\hline Terminal for timber & $37,000,000$ & $25,900,000$ & 2.6 & $96,200,000$ & $67,340,000$ \\
\hline Container Terminal Brajdica & $413,220,000$ & $289,254,000$ & 6.54 & $2,702,458,800$ & $1,891,721,160$ \\
\hline Passenger (line) & $10,000,000$ & $7,000,000$ & 1.33 & $13,300,000$ & $9,310,000$ \\
\hline $\begin{array}{l}\text { Passenger (cruise ships and } \\
\text { other)* }\end{array}$ & 490,200 & 319,200 & 5.97 & $2,926,494$ & $1,905,624$ \\
\hline
\end{tabular}

Source: Made by the authors

utilization, the best results for the surroundings would be achieved by specialized and voluminous container traffic, voluminous bulk cargo traffic as well as tourist-oriented passenger traffic.

\subsubsection{Portion of multiplicated revenue of the Port of Rijeka in the gross domestic product of the Republic of Croatia}

The so far calculated data and results arise from the minimal approximations of all calculations done during the survey. If it's take into consideration the variations of multiplicative factors in realistic frameworks, it could be said that the so far obtained data are sufficiently relevant for comparison in certain wider frameworks. The Port of Rijeka operations realised in 2014, according to the data from this paper, achieved multiple effects on its surroundings. In financial terms and by its operations it achieves at least:

$$
M_{\text {PortRijeka }}=3.19
$$

of direct effects on its surroundings. In case of optimal utilization of capacities, that effect would be at least:

$$
M_{\text {opt }}=3.47
$$

To the Republic of Croatia, the Port of Rijeka represents a port of international economic significance and as such, it has various positive effects on the national economy. A comparison on the level of the GDP of the Republic of Croatia shows that the Port of Rijeka, as an independent transport system, participates with at least 1.618 mld kn i.e. $0.15 \%$ of the GDP. In case of an opti- mal utilization of port terminals that portion would be $0.40 \%$ of the GDP.

In this paper it is repeatedly established from several aspects that the port has multiplicative effects on its surroundings. Every calculation took into consideration only the lowest values and only the direct effects, and it was established that the Port of Rijeka achieves them directly. If higher approximations has been taken into consideration in the existing calculations, and if the effects and a wider spectrum of secondary participants such as shipping companies' revenue, storage charges and fines, as well as tertiary participants i.e. traffic from the wages of physical participants, hospitality, shops, water consumption etc. has been taken into consideration, the multiplicative factor would surely reach the values of 8 or 10, depending on the size of activities taken into consideration. If it was previously established that the Port of Rijeka directly participates with at least $0.15 \%$ in the GDP of the Republic of Croatia, then it is possible to establish the volume of economy it indirectly or consequently effects. If the multiplicative factor of 10 is taken into consideration as approximation of a wider spectrum of the total reach of primary and secondary participants' revenue, it would seem that with its direct and indirect connection, the Port of Rijeka has an effect on more than $1.55 \%$ of the GDP.

In case of an optimal result of port capacities, the reach of influence on the GDP would be 2,83\%. For comparison purposes, on this scale the reach can be measured as a tenth of the GDP, which comprises tourism (17\%) as the most significant economic sector and the greatest contributor to the GDP, which is another proof of the Port of

\begin{tabular}{|c|c|c|c|c|}
\hline & $\begin{array}{l}\text { Total revenue of the } \\
\text { Port of Rijeka (kn) }\end{array}$ & Multiplicative effect (kn) & Mult. factor & GDP ( \%) \\
\hline Maximal theoretical revenue & $1,329,670,200$ & $4,619,060,725$ & 3.47 & 0.40 \\
\hline Theoretical revenue at opt. results ( $70 \%$ of capacities) & $930,745,200$ & $3,233,259,344$ & 3.47 & 0.28 \\
\hline
\end{tabular}

Table 6 Portion in the gross domestic product

Source: Made by the authors 
Table 7 Portion in the gross domestic product in case of a multiplicative factor of 10

\begin{tabular}{|c|c|c|c|c|}
\hline & $\begin{array}{l}\text { Total revenue of the } \\
\text { Port of Rijeka (kn) }\end{array}$ & Max mult. effect (kn) & Mult. factor & GDP (\%) \\
\hline Achieved in 2014 & $507,671,621$ & $5,076,716,211$ & 10.00 & 1.55 \\
\hline Maximal theoretical revenue & $1,329,670,200$ & $13,296,702,000$ & 10.00 & 4.05 \\
\hline Theoretical revenue at opt. results (70 \% of capacities) & $930,745,200$ & $9,307,452,000$ & 10.00 & 2.83 \\
\hline
\end{tabular}

Source: Made by the authors

Rijeka's great influence on the economy of the Republic of Croatia.

\subsubsection{Projection of the further development of the Traffic and Port Services}

It is to be emphasised once again that all models in this paper in the context of calculation of multiplicative effects and factors are formed on the basis of public data, and are not precise enough for definite or absolute conclusions or calculations.

In reality, most tariffs are susceptible to corrections with the purpose of better competitiveness and cooperation on the market, and therefore, the proceeds arising from them could possibly be lower than anticipated in the paper. In spite of that, they can serve as an example of effects arising from the traffic achieved in the Port of Rijeka.

In the context of further development of Rijeka gateway and competitiveness on the market, it is necessary to develop infrastructural capacities of the port system and its hinterland, as well as the traffic connection with larger cities in its gravitational area. Even though the Port of Rijeka has all predispositions to become competitive on the market of North Adriatic ports, further breakthrough will not be possible without adequate mainland infrastructure and great road and railway capacities.

\section{Conclusion}

Ports have always been specific economic subjects which with their operations and services on the market had a developmental effect on their regions, as well as their national economies. If the fact that $90 \%$ of the world trade is done by maritime routes is taken into consideration, it is possible to conclude that ports represent economic zones which drive the development. In accordance with all processed data used in this paper, and discoveries arising from them, it can be concluded that it has once again been confirmed that port transport systems are important factors in many transport routes. In the case of Rijeka gateway, it is clear that with time it is becoming more and more competitive and represented as a cargo route in the interest gravitational area. In that regard, the area of Northern Adriatic is achieving an increasing volume of activities, most of all due to its geostrategic advantages, but also due to the fact that North Adriatic ports are becoming technologically more and more advanced each year. When the Republic of Croatia joined the European Union, many bureaucratic and political barriers were eliminated. That opened a much bigger gravitational market for
Rijeka gateway. With inclusion, functioning and development of infrastructure and services along the European corridor network, Rijeka gateway has witnessed many positive trends in the past few years. The Port of Rijeka acts as a hub of international economic and transport significance for the Republic of Croatia. It is important to mention that with the planned developments and upcoming investments, it is realistic to expect that in the future, Rijeka will establish itself as a respectable port of middle-far range within a larger system of North Adriatic ports. All port preconditions for such achievements have been satisfied, but the main obstructions on that path are still the weak railway capacities as well as the lack of space for extension of port areas. If those obstacles are removed or reduced, the possibilities and reach of the multiplicative influence of the Port of Rijeka would significantly surpass the levels defined in this paper.

\section{References}

[1] Jardas, M.: Significance and role of the Port of Rijeka in transport and economic development of the Republic of Croatia, Journal of Maritime \& Transportation Sciences, 4748, p. 87, 2013.

[2] Kesić, B.: Economics of Ports, University of Rijeka, Faculty of Maritime Studies, Rijeka, 2003.

[3] Marković, I., Muić, M., Vučić, D.: "Position and Development Perspectives of the Port of Rijeka", Journal of Maritime \& Transportation Sciences, 41, 2003.

[4] Zakon o pomorskom dobru i morskim lukama (eng. Maritime Domain and Seaport Act), NN 158/03, 100/04, 141/06, 38/09, 123/11, 56/16.

[5] Main concessionaires of the Port of Rijeka, online: http:// www.portauthority.hr/lucke_usluge/glavni_koncesionari (12.03.2016) Port of Rijeka d.d. - About us, online: http:// www.lukarijeka.hr/hr/o_nama/profil_drustva/default.aspx (11.03.2016)

[6] Port of Rijeka d.d. - Company profile, online: http://www. lukarijeka.hr/hr/o_nama/profil_drustva/default.aspx (15.03.2016)

[7] Port of Rijeka d.d., "Management presentation", online: http://www.lukarijeka.hr/hr/press_room/prezentacije/ default.aspx (01.04.2016)

[8] Port of Rijeka d.d Report for2014, online: http://www.lukarijeka.hr/hr/investitori/izvjesca_i_obavijesti/financijska_izvjesca/default.aspx (02.03.2016)

[9] Management Board's Report on the Port of Rijeka Group's Business Activities, online: http://www.lukarijeka.hr/_Data/Files/196_20150730143656263/Konsolid.financ.izvje \%C5\%A1\%C4\%87e\%20za\%20prvo\%20 polugodi\%C5\%A1te\%202015.pdf (10.04.2016) 